\title{
Prevalence of bromide in groundwater in selected regions in South Africa
}

\author{
HL Lucht ${ }^{1}$ and $\mathrm{NH}$ Casey ${ }^{1}$ \\ 'Department of Animal and Wildlife Sciences, University of Pretoria, South Africa
}

\begin{abstract}
Many regions across South Africa are dependent on groundwater as the only water source for livestock watering and domestic use. This paper presents an analysis of 350 water samples from collated data of 5 reports published between 2001 and 2016 that show the vast range of $0-132.68 \mathrm{mg} / \mathrm{L}$ bromide $\left(\mathrm{Br}^{-}\right)$present in South African groundwater. It further highlights that $\mathrm{Br}^{-}$may be a greater toxicity risk factor to livestock production and human health as an endocrine disrupting chemical (EDC) and through accumulation in organs than previously considered. Further validation is required of the physiological effects of $\mathrm{Br}^{-}$for inclusion in water quality guidelines (WQG). Attention is drawn to the importance of site-specific water quality (WQ) monitoring and identification of vulnerable populations to enable adequate risk assessment and implementation of mitigating strategies to lower exposure risk in a specific area.
\end{abstract}

Keywords: bromine, halide, toxicity, water quality

\section{INTRODUCTION}

Many regions across South Africa are dependent on groundwater as the only water source for extensive and intensive livestock production, and wildlife in game farming and game reserves. In remote regions, domestic households might also be dependent on groundwater, as access to surface water or roof-harvested rainwater could be erratic, and therefore exposed to potentially hazardous elements. Initially health problems were reported in livestock in specific areas and fluorosis was identified as a major problem (Coetzee et al., 1997; 2000). Water samples were collected at various points from source and use-points for the purpose of compiling reports addressing the risk presented to livestock. Chemical analysis of water quality constituents (WQC) of the earliest water samples confirmed the presence of fluoride in excess of reported water quality guideline (WQG) safe levels. This information was used to determine an appropriate method of risk assessment and subsequent decision-making on fitnessfor-use (FFU) of available water sources.

The initial focus of early research was to formulate and test solutions to most frequently identified palatability and toxicological water quality (WQ) problems of groundwater drawn from wells, springs and boreholes (Casey et al., 1998). Increased efforts to measure and assess the potential risk posed by geochemistry-related factors resulted from advances in identifying the role of inorganic constituents on the epidemiology of non-differential clinical symptoms commonly observed in livestock (Meyer et al., 2000).

As more information emerged, objectives of the research projects changed to include analysis of multiple elements in water sampled from various regions across South Africa. It emerged from those research projects that bromide $\left(\mathrm{Br}^{-}\right)$was present in many of the samples collected from areas already identified as at-risk of exposure to known hazardous elements It further emerged that $\mathrm{Br}^{-}$was present at potentially harmful concentrations for many of the selected sites.

There were no formal international or local WQG available for $\mathrm{Br}^{-}$because it was initially merely acknowledged as a

${ }^{*}$ Corresponding author, email: h.lucht@gmail.com

Received 28 June 2018; accepted in revised form 14 June 2019 ubiquitous micro-element of unknown essentiality and not considered problematic. Similarly, water was ignored as a nutrient. Traditionally the focal point of deficiency or toxicity research was limited to the contribution of micronutrients from premixes to nutrient composition of feed. As research progressed over time, a very different picture emerged and raised many questions. It emphasised that water should be given closer attention as a potential source of micro-elements in human and livestock nutrition (Casey and Meyer, 2001).

This paper presents collated results of data collected in selected regions in 6 provinces in South Africa and published in various reports between 2001 and 2016. The aims of the Water Research Commission (WRC) and other sponsored research were to determine FFU of water for livestock production. This was extended to include game such as ostrich production. The aim of this paper was to show the considerable range of $\mathrm{Br}$ concentrations present in groundwater in selected regions, and to draw attention to the reality that $\mathrm{Br}^{r}$ may have a much greater impact on animal production than previously considered.

\section{MATERIALS AND METHODS}

Data of groundwater $\mathrm{Br}$ concentrations were collated from water sample results (Table 1). The reports from which the data were collated were not all in the same format. Sampling for each report was done according to the objectives of the individual report, which resulted in an uneven dataset. There were no GPS co-ordinates available for points sampled for earlier reports and thus compilation of a distribution map for this paper was not possible.

Data were sorted according to sample source (Table 2) and locality across years and seasons to obtain information of overall $\mathrm{Br}^{-}$concentrations present in groundwater used for livestock production and household use across selected regions. The majority of the samples were collected in areas where the human and livestock populations were dependent on groundwater as the only source of water for drinking and domestic use.

Initially potentially problematic physiologically significant trace elements were identified according to the specific requirements of each individual project prior to water sample collection. All water samples were collected for the 
completion of individual reports using the same method, and all samples were analysed using inductively coupled plasma atomic emission spectrometry (ICP-AES) techniques with full quantitative and semi-quantitative procedures by the Institute for Soil, Climate and Water at the Agricultural Research Council (ARC-ICSW), Pretoria. Elements present in the samples were classified as constituents of concern (COC) or potentially hazardous chemical constituents (PHCC) according to their presence at concentrations relative to local and international WQG standards. Not all elements were present in all water samples, and for the purpose of this paper, only $\mathrm{Br}^{-}$ concentrations were considered.

Where possible, water samples were collected at source from wells, springs and boreholes, from the surface of reservoirs, tanks or drinking troughs supplied by boreholes and at use-points such as from taps or water lines in poultry houses (Table 2). In WRC reports published before 2001, $\mathrm{Br}^{-}$was not included as a COC, but as time progressed and the objectives of the projects expanded, it emerged from the various case studies that $\mathrm{Br}^{-}$should be included in further testing. A total of 350 groundwater samples were ranked from highest to lowest $\mathrm{Br}^{-}$ concentrations across all years, sources, seasons and localities to determine the overall range of $\mathrm{Br}^{-}$present in groundwater in a South African context. Water samples were grouped by collection source within province to determine an overall picture of how $\mathrm{Br}^{-}$concentration may vary in different sample sources within a locality.

\section{RESULTS AND DISCUSSION}

Inconsistent sampling techniques, such as sample collection by different technicians and variations in sample collection depth, and inconsistent or seasonal use of boreholes in some areas could explain the occurrence of unavoidable sampling errors with effects on the accuracy of measurements.

It emerged from the collated data that the overall range of $\mathrm{Br}^{-}$concentrations present in groundwater sampled across selected regions in South Africa was 0-132.68 mg/L.

Samples taken from dams, source, reservoirs and usepoints included in the dataset were limited to those supplied by boreholes (Tables 2 and 3).

There were distinct differences in $\mathrm{Br}^{-}$concentrations between sources within and across regions (Tables 2 and 3). The majority of water samples collected were for selected areas in the North West and Limpopo Provinces in accordance with the specific objectives of projects undertaken to address areaspecific problems reported within those provinces.

Groundwater sampled from reservoirs showed higher $\mathrm{Br}^{-}$ concentration compared with groundwater sampled at source,
Table 1. WRC Reports used for data collation

\begin{tabular}{ll}
\hline Report & Author \\
\hline WRC 857/1/01 & Casey and Meyer, 2001 \\
WRC 857/2/01 & Casey, Meyer and Coetzee, 2001 \\
032005/02/26 & Meyer, 2005 \\
WRC 1175/1/06 & Casey and Meyer, 2006 \\
WRC 2175/2/16 & Korsten, Casey and Chidamba, 2016 \\
\hline
\end{tabular}

Table 2. $\mathrm{Br}^{-}$concentrations (mg/L) within source across all years, all seasons, all localities

\begin{tabular}{lrrrrr}
\hline Sample & \multicolumn{1}{c}{$\boldsymbol{n}$} & Min & Max & $\boldsymbol{\mu}$ & \multicolumn{1}{c}{ SE } \\
\hline Dam & 2 & 0.79 & 0.84 & 0.81 & 0.04 \\
Source & 269 & ND $^{*}$ & 132.68 & 3.52 & 14.53 \\
Reservoir & 63 & 0.01 & 6.44 & 0.80 & 1.19 \\
Use-point & 16 & 0.01 & 0.38 & 0.17 & 0.12 \\
\hline
\end{tabular}

${ }^{*} \mathrm{ND}=$ not detected

with the exception of the 97 water samples collected at source in Limpopo Province (Table 3). Many factors, such as depth of sampling, sampling site, water flow rate, water usage rate, and pumping frequency could influence the accuracy of the measurement of a WQC in a definitive water sample of the source, and $\mathrm{Br}^{-}$is no exception. However, since it is not possible with current technology to verify the measured concentration, it was assumed that each sample was an accurate representative sample and the measurement an accurate estimation of the concentration of a WQC at the time of sampling.

Water stored in open reservoirs or held in drinking troughs that are not subject to high stocking rates or frequent use are expected to contain higher concentration of $\mathrm{Br}^{-}$than water sampled at source or at use-point. This is because exposure of open troughs and reservoirs to evaporation results in a concentrating effect on $\mathrm{Br}^{-}$within that water body, which is true for all WQC. Groundwater pumped into open reservoirs exposed to $\mathrm{UV}$ radiation is subject to speciation of $\mathrm{Br}^{-}$in the presence of oxygen to form bromate $\left(\mathrm{BrO}_{3}\right)$. The rate of conversion is dependent on $\mathrm{pH}$ and presence of other elements. This speciation of $\mathrm{Br}^{-}$is potentially hazardous since $\mathrm{BrO}_{3}$ is a known carcinogen (Jain et al., 1996; DeAngelo et al., 1998; Magazinovic et al., 2004; Bonacquisti, 2006; Moore and Chen, 2006). Similarly, water sampled from pipes exposed to sun may differ in composition to water sampled at source because the rate of elemental interactions within water accelerates with heating (Table 2).

The current South African WQG for livestock watering does not list $\mathrm{Br}^{-}$as either a COC or PHCC (Casey and Meyer, 1996). It is common for products of endocrine disrupting chemical (EDC) metabolism to be more toxic than the parent

Table 3. $\mathrm{Br}^{-}$concentrations ( $\mathrm{mg} / \mathrm{L}$ ) in groundwater in selected regions clustered by province

\begin{tabular}{|c|c|c|c|c|c|c|c|c|c|c|c|}
\hline Sample & $n$ & $\min$ & $\max$ & $\mu$ & SE & Sample & $n$ & Min & $\max$ & $\mu$ & SE \\
\hline \multicolumn{6}{|c|}{ North West } & \multicolumn{6}{|c|}{ Western Cape } \\
\hline Source & 141 & 0.00 & 2.14 & 0.31 & 0.37 & Source & 13 & 0.04 & 6.60 & 3.11 & 2.01 \\
\hline Reservoir & 36 & 0.03 & 2.09 & 0.42 & 0.55 & Reservoir & 5 & 2.43 & 6.44 & 3.82 & 1.62 \\
\hline Use point & 16 & 0.01 & 0.38 & 0.17 & 0.12 & & & & & & \\
\hline \multicolumn{6}{|c|}{ Limpopo } & \multicolumn{6}{|c|}{ KwaZulu-Natal } \\
\hline Dam & 2 & 0.79 & 0.84 & 0.81 & 0.04 & Source & 5 & 0.01 & 0.23 & 0.12 & 0.09 \\
\hline Source & 97 & 0.01 & 132.68 & 8.87 & 23.29 & & & & & & \\
\hline Reservoir & 22 & 0.01 & 2.98 & 0.74 & 0.88 & & & & & & \\
\hline \multicolumn{6}{|c|}{ Mpumalanga } & \multicolumn{6}{|c|}{ Eastern Cape } \\
\hline Source & 6 & 0.05 & 0.25 & 0.14 & 0.09 & Source & 6 & 0.06 & 0.37 & 0.21 & 0.13 \\
\hline
\end{tabular}


compound (Burger, 2005). An EDC is any naturally occurring or synthetic chemical that interferes with the structure or function of hormone receptor complexes, either in an antagonistic or synergistic way, to alter the correct function of an endocrine response within a target organ (Bornman et al., 2007). The USEPA (1997) expands the definition of an EDC to include that the exogenous substance causes adverse health effects in the intact organism, its progeny or (sub) populations. EDCs commonly monitored for hazards to human and animal health are usually lipophilic organic compounds with oestrogenic properties (Bornman et al., 2007). Naturally occurring $\mathrm{Br}^{-}$is a hydrophilic inorganic element identified as an EDC in rats (Loeber et al., 1983) and chickens (Du Toit and Casey, 2012) and is expected to have the greatest direct disrupting effect on metabolism in vulnerable livestock and human populations.

The report by Casey and Meyer (2001) lists $\mathrm{Br}^{-}$with a maximum permissible level (MPL) of $1-3 \mathrm{mg} / \mathrm{L}$ and a crisis level of $6 \mathrm{mg} / \mathrm{L}$, with the recommended limit set at $1 \mathrm{mg} / \mathrm{L}$ due to risk of $\mathrm{BrO}_{3}$ formation at that concentration. A subsequent report (Casey and Meyer, 2006) introduced $0.01 \mathrm{mg} / \mathrm{L}$ as a maximum contaminant level (MCL) to align it with USEPA (2005) guidelines. Faced with conflicting reports of what constituted a safe minimum concentration against which to compare results obtained from field samples, Casey (2016) accepted a minimum level of $0.01 \mathrm{mg} / \mathrm{L}$ as a point of departure for analysis and interpretation of the test results. This was in line with the accepted default maximum residue level (MRL) of $1 \mathrm{mg} / \mathrm{kg}$ used for most food additives not yet validated in terms of Regulation (EC) No. 396/2005 (European Parliament, 2005).

Traditional WQG propose generic safety levels of elements based on concentration-based estimates, which assume a linear relationship between the concentration of an element in source and its effects in vivo. Limitations of such a generic approach are that the accepted safety limits of elements in feed and water are seldom published in the same guidelines, and limited differentiation exists between different types of livestock or game species where applicable. Further limitations are that interactions between elements in the same source are ignored and the assumption that all groundwater sources in the same area are of equal quality.

The disadvantage of a concentration-based approach is that exposure risk is disregarded as being multifactorial when it is influenced by any factor that affects water intake rate or physiological state of an individual. Intake-based guidelines that are site-specific will better estimate exposure risk of a target population, thus allow for better mitigation of adverse effects.

All elements, whether essential or nonessential, can exert toxic effects when consumed in excess through water or feed, which includes minerals occurring in feed and water at trace levels otherwise regarded as incidental contaminants with no obvious important nutritional role (NRC, 2005). PHCC have adverse effects at relatively low levels, and magnitude of exposure risk depends on exposure period duration (Plant et al., 1996). Low-dose, long-term exposure to PHCC will most likely manifest in subclinical responses where toxicity is expressed as secondary induced deficiencies, making toxicity symptoms difficult to identify (Meyer and Casey, 2004). Similarly, EDCs exert their effect at very low exposure levels (Bornman et al., 2007).

The vast range in $\mathrm{Br}$ concentrations in water sampled from Limpopo Province compared with other provinces (Table 3) draws attention to the importance of site-specific analysis of groundwater sources when determining FFU of such sources and the potential risk of vulnerable population exposure to hazardous chemical constituents. Site-specific risk assessment requires that geochemical factors on soil and plant concentrations be included in the total exposure risk estimation for a given area to enable formulation of contextual solutions (Meyer et al., 2000).

Some areas were chosen for sampling to determine the quality of alternative water sources in provinces that were not solely dependent on groundwater, in line with the research objectives to generate specific reports. This resulted in collection of relatively few groundwater samples from those provinces compared with areas where groundwater played a greater role (Table 3 ).

Many environmental health effects caused by nutritional element excess and deficiencies in South African agricultural systems have been documented, yet there are still health impacts of potentially harmful elements that are less known (Davies and Mundalamo, 2010). Heavy metals are known to be toxic due to their cumulative nature and cause increasing damage to brain, kidney and nervous system with extended exposure periods (Ezekwe et al., 2012). Similarly, $\mathrm{Br}^{-}$has been shown to accumulate in liver, kidney and thyroid tissue $(\mathrm{Du}$ Toit and Casey, 2012; Mamabolo et al., 2009). Further fieldwork done by Meyer (2005) included tissue sampling and revealed evidence that $\mathrm{Br}^{-}$had histopathological effects on thyroid and other tissues in commercial broilers reared in areas where $\mathrm{Br}^{-}$concentrations in groundwater were high. It is known that $\mathrm{Br}^{-}$has the ability to circulate freely and rapidly into the extracellular fluid and various tissues of the body except the central nervous system (Pavelka et al., 2000). This free movement throughout the body affords $\mathrm{Br}^{-}$the opportunity to interfere with multiple biochemical processes. Although further validation is required, it appears that $\mathrm{Br}^{-}$could be labelled an EDC, which is a concern for livestock farmers and people who might be exposed to $\mathrm{Br}^{-}$in drinking water.

Identifying $\mathrm{Br}^{-}$as a COC or PHCC in water sources of areas where no alternative water sources were available raised further questions about the best ways to define and identify vulnerable populations to determine FFU of these water sources. Risk assessment relies on the identification of vulnerable populations within an area, because water requirements will differ between groups within a population according to age and physiological state (Table 4). Vulnerable populations in livestock production include neonates, very young and actively growing animals, immunocompromised animals and pregnant and lactating females. Where multispecies water use is common, such as in game reserves with watering holes supplied by borehole water, interspecies differences in mineral tolerance must be considered in the FFU decision-making process due to the different species-specific metabolic requirements related to physiological state. Bornman et al. (2007) stated that EDCs can pose risks to reproductive function, immunity, thyroid function and neurodevelopment, dependent on the type of substance and its toxicodynamic and toxicokinetic mechanisms of action.

The geochemical character of groundwater depends on mineral chemistry of aquifer materials and biomediated ion exchange reactions (Ezekwe et al., 2012). Changes in environment such as ambient temperature, feed composition and water palatability influence water intake. Physiological differences between groups translate to differences in metabolism and assimilation rates of elements. Exposure risk depends on the per capita consumption of an element relative to body weight (Ezekwe et al., 2012) and this is clearly shown in Table 4. Immature and actively growing individuals are thus at greatest risk of developing toxicity symptoms from relatively 
Table 4. Estimated intake of $\mathrm{Br}$ through water by humans

\begin{tabular}{|c|c|c|c|c|c|c|}
\hline \multirow{2}{*}{ Persons } & \multirow{2}{*}{$\begin{array}{l}\text { WQG } \\
\mathrm{mg} / \mathrm{L}\end{array}$} & \multicolumn{2}{|c|}{$\mathrm{Br}^{-}$in water $(\mathrm{mg} / \mathrm{L})$} & \multirow{2}{*}{$\begin{array}{c}\text { Water Intake } \\
\text { L/day* }\end{array}$} & \multicolumn{2}{|c|}{$\mathrm{Br}^{-} /$day by WI (mg) } \\
\hline & & Max & $\mu$ & & Max & $\mu$ \\
\hline Males: adults and adolescents & 0.01 & 133 & 3 & 2.30 & 305 & 7 \\
\hline Children: both sexes 4-12 yr & 0.01 & 133 & 3 & 0.55 & 73 & 2 \\
\hline Children: both sexes $0-3 \mathrm{yr}$ & 0.01 & 133 & 3 & 0.40 & 53 & 1 \\
\hline Women: pregnancy $<18 \mathrm{yr}$ & 0.01 & 133 & 3 & 2.30 & 305 & 7 \\
\hline Women: pregnancy $19-50 \mathrm{yr}$ & 0.01 & 133 & 3 & 2.30 & 305 & 7 \\
\hline Women: lactating < $18 \mathrm{yr}$ & 0.01 & 133 & 3 & 2.90 & 385 & 8 \\
\hline Women: lactating $19-50 \mathrm{yr}$ & 0.01 & 133 & 3 & 2.90 & 385 & 8 \\
\hline
\end{tabular}

${ }^{*}$ Assumed for normal healthy people of moderate lifestyle at $95 \%$ of the empirical distribution $(E P A, 2004)$

lower concentrations of COC or PHCC due to a combination of limited capacity of immature organs for adequate detoxification, and greater rates of assimilation of elements by tissues with high metabolic activity (Table 4 ). As a result, it is common practice to assign water sources of relatively poorer FFU scores to the least vulnerable groups within a population when alternative water sources are unavailable. In some cases, where practical, water treatment can improve its elemental quality sufficiently to make it safe for use.

The use of sentinel species is a useful tool to evaluate risk to vulnerable populations over time. Meyer (2015) used indigenous chicken breeds and commercial broiler chickens produced in a specific locale as a reference point for risk assessment of groundwater containing high concentrations of $\mathrm{Br}^{-}$for the selected area. The additional collection of multiple tissue sample types from sentinel species, together with single water samples, allowed for better identification of chronic exposure risk to PHCC than water sampling alone, with liver samples reported to be the most appropriate tissue sample for assessment of $\mathrm{Br}^{-}$exposure risk (Casey and Meyer, 2006). The most suitable choice of sentinel species in an area will depend on specific monitoring objectives and the practicality of tissue sample collection for testing. Future consistent sampling of the same sites over time will garner more information on the toxicity risk that $\mathrm{Br}^{-}$in groundwater poses to populations in the area at different times of the year and in different situations. Monitoring specific groundwater sources could indicate which water usage patterns could effectively limit exposure of vulnerable populations to COC and PHCC.

\section{CONCLUSION}

The considerable range of concentrations of $\mathrm{Br}^{-}$occurring in South African groundwater presented in this paper draws attention to the importance of monitoring site-specific WQ for FFU assessment for domestic and livestock use. It further highlights that $\mathrm{Br}^{-}$may be a greater toxicity risk factor to livestock production and human health than previously considered. In order to be included in WQG, further validation is required on the physiological effects of $\mathrm{Br}^{-}$and associated risk factors. Identification of vulnerable populations is paramount to the selection of the best solution to alleviate risks of exposure to $\mathrm{Br}^{-}$in groundwater. Continued seasonal monitoring is recommended to identify potential risks linked to changes in WQ and to assist in the diagnosis of physiological anomalies.

\section{ACKNOWLEDGEMENTS}

The authors wish to acknowledge the Water Research Commission of South Africa and Dr JA Meyer for access to the published report 032005/02/26, and the National Research
Foundation for funding through the incentive grant to NHC, reference: PR-IFR180205310035/UID96806.

\section{REFERENCES}

BONACQUISTI TP (2006) A drinking water utility's perspective on bromide, bromate and ozonation. Toxicology 221 145-148. https:// doi.org/10.1016/j.tox.2006.02.010

BORNMAN MS, VAN VUREN JH, BOUWMAN H, DE JAGER C, GENTHE B and BARNHOORN EJ (2007) The use of sentinel species to determine the endocrine disruptive activity in an urban nature reserve. WRC Report No. 1505/1/07. Water Research Commission, Pretoria. ISBN 978-1-77005-551-3.

BURGER AEC (2005) WRC programme on endocrine disrupting compound (EDCs): Volume 1: Strategic research plan for endocrine disrupters in South African water systems. WRC Report No. KV 143/05. Water Research Commission, Pretoria. ISBN 1-77005-348-4.

CASEY NH (2016) Inorganic chemical quality of water. In: Korsten L, Casey $\mathrm{NH}$ and Chidamba L (eds.) Evaluation of the risks associated with the use of rooftop harvesting and groundwater for domestic use and livestock watering. Volume 2: Chemical quality of groundwater for potable use and livestock watering. WRC Report No. 2175/2/16. Water Research Commission, Pretoria. ISBN 978-1-4312-0875-3. https://doi.org/10.3133/wri834008

CASEY NH and MEYER JA (1996) In: Holmes S (ed.) South African Water Quality Guidelines. Volume 5: Agricultural Use: Livestock Watering. Department of Water Affairs and Forestry, Pretoria.

CASEY NH and MEYER JA (2001) An extension to and the further refinement of a water quality guideline index system for livestock watering: Volume 1: Rural communal livestock production systems and wildlife production systems. WRC Report No. 857/1/01. Water Research Commission, Pretoria. ISBN 1-86845-713-3.

CASEY NH and MEYER JA (2006) The application of risk assessment modelling in groundwater for humans and livestock in rural communal systems. WRC Report No. 1175/1/06. Water Research Commission, Pretoria. ISBN 1-77005-467-7.

CASEY NH, MEYER JA and COETZEE CB (1998a) An investigation into the quality of water for livestock production with the emphasis on subterranean water and the development of a water quality guideline index system. Volume 1: Development and modelling. WRC Report No. 644/1/98. Water Research Commission, Pretoria. ISBN 1-86845-739-0.

CASEY NH, MEYER JA and COETZEE CB (1998b) An investigation into the quality of water for livestock production with the emphasis on subterranean water and the development of a water quality guideline index system. Volume 2: Research results. WRC Report No. 644/2/98. Water Research Commission, Pretoria. ISBN 1-86845-380-4.

CASEY NH, MEYER JA and COETZEE CB (1998c) An investigation into the quality of water for livestock production with the emphasis on subterranean water and the development of a water quality guideline index system. Volume 3: Appendix. WRC Report No. 644/3/98. Water Research Commission, Pretoria. ISBN 1-868457-381-2.

CASEY NH, MEYER JA and COETZEE CB (2001) An extension to 
and further refinement of a water quality guideline index system for livestock watering. Volume 2: Poultry production systems and water quality for ostrich production. WRC Report No. 857/2/01. Water Research Commission, Pretoria. ISBN 1-86845-714-1.

COETZEE CB, CASEY NH and MEYER JA (1997) Fluoride tolerance in layers. Br. Poult. Sci. 38 597-602.

COETZEE CB, CASEY NH and MEYER JA (2000) The effect of waterborne fluoride on the production of laying hens. Water SA 26 (1) $115-118$.

DAVIES TC and MUNDALAMO HR (2010) Environmental health impacts of dispersed mineralisation in South Africa. J. Afr. Earth Sci. 58 652-666. https://doi.org/10.1016/j.jafrearsci.2010.08.009

DEANGELO AB, GEORGE MH, KILBURN S, MOORE TM and WOLF DC (1998) Carcinogenicity of potassium bromate administered in the drinking water to male $\mathrm{B} 6 \mathrm{C} 3 \mathrm{~F} 1$ mice and F344/N rats. Toxicol. Pathol. 26 587-594. https://doi. org $/ 10.1177 / 019262339802600501$

DU TOIT J and CASEY NH (2012) Iodine as an alleviator of bromine toxicity in thyroid, liver and kidney of broiler chickens. Livest. Sci. 144 269-274. https://doi.org/10.1016/j.livsci.2011.12.011

EUROPEAN PARLIAMENT (2005) Regulation (EC) No 396/2005 of the European Parliament and of the Council of 23 February 2005 on maximum residue levels of pesticides in or on food and feed of plant and animal origin and amending Council Directive 91/414/ EEC. Official Journal of the European Union, 2005R0396 - EN 26.10.2012 - 010.001. https://doi.org/10.1007/978-1-137-54482-7_24

EZEKWE IC, ODU NN, CHIMA GN and OPIGO A (2012) Assessing regional groundwater quality and its health implications in the Lokpaukwu, Lekwesi and Ishiagu mining areas of southeastern Nigeria using factor analysis. Environ. Earth Sci. 67 971-986. https://doi.org/10.1007/s12665-012-1539-9

JAIN A, CHAURASIA A, SAHASRABUDDHEY B and VERMA KK (1996) Determination of bromide in complex matrices by pre-column derivatization linked to solid-phase extraction and high-performance liquid chromatography. J. Chromatogr. A 746 (1) 31-41. https://doi.org/10.1016/0021-9673(96)00317-2

KORSTEN L, CASEY NH AND CHIDAMBA L (2016) Evaluation of the risks associated with the use of rooftop harvesting and groundwater for domestic use and livestock watering: Volume 2: WRC Report No. 2175/2/16. Water Research Commission, Pretoria. ISBN 978-1-4312-0875-3.

LOEBER JG, FRANKEN MAM and VAN LEEUWEN FXR (1983) Effect of sodium bromide on endocrine parameters in the rat as studied by immunocytochemistry and radioimmunoassay. Fd. Chem. Toxic. 21 (4) 391-404. https://doi. org/10.1016/0278-6915(83)90093-5

MAGAZINOVIC RS, NICHOLSON BC, MULCAHY DE and DAVID DE (2004) Bromide levels in natural waters: its relationship to both levels of chloride and total dissolved solids and the implications for water treatment. Chemosphere 57 329-335. https://doi.org/10.1016/j. chemosphere.2004.04.056
MAMABOLO MC, CASEY NH and MEYER JA (2009) Effects of total dissolved solids on the accumulation of $\mathrm{Br}, \mathrm{As}$ and $\mathrm{Pb}$ from drinking water in tissues of selected organs in broilers. S. Afr. J. Anim. Sci. 39 (1) 169-172. https://doi.org/10.4314/sajas.v39i1.61227

MEYER JA (2005) Project: Analyse borehole water for domestic use and livestock watering throughout the Republic of South Africa for a period of one year. Department of Agriculture Report No. 032005/02/26. Department of Agriculture, Pretoria.

MEYER JA (2015) Animal health assessment. In: Dabrowski JM (ed.) Investigation of the contamination of water resources by agricultural chemicals and the impact on environmental health Volume 1: Risk assessment of agricultural chemicals to human and animal health. WRC Report No. 1956/1/15. Water Research Commission, Pretoria. ISBN 978-1-4312-0711-4.

MEYER JA and CASEY NH (2004) Exposure assessment of potentially toxic trace elements in indigenous goats in the rural communal production systems of the northern region of South Africa. S. Afr. J. Anim. Sci. 34 (Suppl 1) 219-222.

MEYER JA, CASEY NH and MYBURGH J (2000) The influence of geochemistry on health risks to animals and humans in geographically localised livestock production systems. S. Afr. J. Anim. Sci. 30 (Supplement 1) 82-84. https://doi.org/10.4314/sajas. v30i4.3920

MOORE MM and CHEN T (2006) Mutagenicity of bromate: Implications for cancer risk assessment. Toxicology 221 190-196. https://doi.org/10.1016/j.tox.2005.12.018

NRC (2005) Bromine In: Klasing KC (ed.) Mineral Tolerance of Animals: Second revised edition. Committee on Minerals and Toxic Substances in Diets and Water for Animals, National Research Council, Washington, DC.

PAVELKA S, BABICKÝ A, VOBECKÝ M, LENER J and ŠVANDOVÁ $\mathrm{E}$ (2000) Bromide kinetics and distribution in the rat. I. Biokinetics of ${ }^{82} \mathrm{Br}$-Bromide. Biol. Trace Elem. Res. 76 57-66. https://doi. org/10.1385/bter:76:1:57

PLANT JA, BALDOCK JW and SMITH B (1996) The role of geochemistry in environmental and epidemiological studies in developing countries: a review. In: Appleton JD, Fuge R and McCall GJH (eds.) Environmental Geochemistry and Health Geological Society Special Publication No. 113. Geological Society, London. https://doi.org/10.1144/gsl.sp.1996.113.01.02

USEPA (United States Environmental Protection Agency) (1997) Special report on environmental endocrine disruption: An effects assessment and analysis. Report No EPA/630/R-96/012. United States Environmental Protection Agency, Washington D.C. https:// doi.org/10.2172/569107

USEPA (United States Environmental Protection Agency) (2005) Domestic Drinking Water Quality Criteria. National Technical Information Service. United States Environmental Protection Agency, Washington D.C. https://doi.org/10.2172/569107 